\title{
Study of Clinical Correlates of Tubercular Meningitis in a Tertiary Care Centre in Moradabad
}

\author{
Vikramjeet Singh Malik', V. K. Singh ${ }^{2}$ \\ ${ }^{1}$ Post Graduate Student, Department of Medicine, TMMC\&RC, Moradabad, India, ${ }^{2}$ Professor \& Head, Department of Medicine, TMMC\&RC, Moradabad, \\ India.
}

\section{Abstract}

Background: Tuberculosis continues to remain a leading cause of mortality worldwide with tubercular meningitis being the most common type of central nervous system tuberculosis that is associated with significant morbidity and mortality if not identified and treated promptly. Due to meager amount of published data and lack of evaluation of the western UP population, this study was conducted in order to observe a detailed clinical course of the disease as well as to analyze predictors of morbidity and mortality in patients of TBM admitted at a tertiary care hospital in Moradabad.Subjects and Methods: A total of 120 patients with diagnosis of TBM as per the diagnostic criteria of the study were included and all their information and features recorded and treatment done as per guidelines and a follow-up done at 3 months using Barthel Index.Results: Multivariate logistic regression analysis of various factors revealed age of the patient $(\mathrm{p}=0.04)$, duration of symptoms $(\mathrm{p}=0.002)$, stage of TBM on presentation ( $\mathrm{p}=0.001)$, TLC $>9000 \quad(\mathrm{p}=0.006)$, low CSF glucose ( $\mathrm{p}=0.01)$, hyponatremia ( $\mathrm{p}=0.04)$, hypoalbuminemia $(\mathrm{p}=0.007)$ and hydrocephalus $(\mathrm{p}=0.04)$ on neuroimaging were significant risk factors of mortality and morbidity in adult patients of TBM.Conclusion: The current study may provide components for the composition of a score to predict outcome using the significant poor prognostic factors that were recognized in this study. This can be utilised for prompt employment of rigorous management remedies in order to reduce patients' morbidity and mortality.

Keywords: Tubercular Meningitis, HIV, CSF.

Corresponding Author: V. K. Singh, Professor \& Head, Department of Medicine, TMMC\&RC, Moradabad, India.

Received: December 2019

Accepted: December 2019

\section{Introduction}

Tuberculosis has continued to persist as a leading disease worldwide and still remains amongst the top 10 causes of death throughout the globe. 2018 hadaround 1.2 million TB patients expiring amongst the HIV negative patientsand 2,51,000 expiring amongst the HIV positive patients. Approximately 10 million new patientsdeveloped $\mathrm{TB}$ in 2018. Majority of new cases in 2018 occurred in the WHO South-East Asia Region (44\%). Countries with maximum share of the incidental disease burden (2/3rd) in 2018 were India having maximum cases $(27 \%)$ followed in a descending order by China, Indonesia, Philippines, Pakistan and Bangladesh from Asia and from Africa the nations being Nigeria and South Africa. ${ }^{[1]} 5$ to $15 \%$ cases of extra pulmonary tuberculosis affect nervous system with TBM being the commonest type constituting $70 \%$ cases of TB of the neurological system. ${ }^{[2]}$

Tubercular meningitis is a disease that should be ruled out in all patients with fever presenting with altered sensorium.It is a disease that requires early diagnosis and treatment to achieve complete cure rate without sequelae. This study would help create a profile of patients belonging to western UP region in order to help in better and early identification of relatively less common manifestations specific to this population and to reduce morbidity and mortality in such cases.

Tuberculous meningitis (TBM)being the most prevalent type of central nervous system tuberculosis is linked with greater incidence of neurologic sequelae as well as mortality if not swiftly managed thus remains a significant threat to the health and wellbeing of patients in developing nations. ${ }^{[3-7]}$ The TBM severity has been ascertained using a TBM grading system that is named after its creators called British Medical Research Council(MRC) grading that is based on the patient's GCS and the presence of focal neurological deficits. ${ }^{[8]}$

Thorough understanding of the disease's clinical course and timely evaluation for complications is necessary for prompt treatment, in order to avert complications as well as avert morbidity and high mortality in the TBM cases.

Due to meager amount of published data and lack of evaluation of the western UP population, this study was conducted in order to observe a detailed clinical course of the disease as well as to analyze predictors of morbidity and mortality in patients of TBM admitted at a tertiary care hospital in Moradabad.

\section{$\underline{\text { Aim }}$}

- To study the clinical correlates of tubercular meningitis. 
Objectives

- To study various clinical features of patients with tubercular meningitis.

- To study the complications and sequelae of patients with tubercular meningitis.

- To see the predictors of morbidity and mortality in tuberculous meningitis patients and to assess their outcome.

\section{Subjects and Methods}

All patients admitted with clinical features, CSF examination and neuroimaging study suggestive of tuberculous meningitis according to our study's criteria, presenting during the duration of study were recruited in the study. The study details and purpose was elucidated to patients and/or their attendants and informed consent was taken from them, additionally, in case of comatose patient, consent was taken taken from the next of kin. As per pro forma details of the patients' demographical details, clinical history and examination findings were documented and evaluation with lab investigations, CSF examination and neuroimaging were performed. Patients were appraised for complications during their hospital stay and accordingly managed. Patients diagnosed were treated with anti-tubercular drugs at recommended doses by latest RNTCP guidelines. Additionally, corticosteroids were given in the initial management of the patients. Mannitol was given in cases where raised intracranial pressure was suspected or hydrocephalus was present. When possible neurosurgical reference was done for hydrocephalus. A follow-up protocol was be devised and all the patients and their relatives were counseled about follow-up. Follow was performed at 3 months either by direct interview and observations on an outpatient basis, or in a telephone interview of the patient. Outcome was determined by utilizing Barthel Index (BI) score at the time of follow up after 3 months into poor $(\mathrm{BI}<12)$ and good recovery $(\mathrm{BI}>12)$ as in a multivariate analysis by Misra et al. ${ }^{[9]}$

\section{Inclusion Criteria}

- All patients with diagnosis of TBM as per the diagnostic criteria in the study.

\section{Exclusion Criteria}

- All patients with meningitis due to causes other than tuberculosis, viral encephalitis, sub-arachnoid hemorrhage and intracerebral bleed

- Patients not giving consent for participation in the study were excluded from the study.

\section{Statistical Analysis}

- All patients fulfilling the diagnostic criteria of the study presenting during the duration of study were included in the study, their total being 120 . The clinical and investigation parameters of these 120 patients were collected (after taking consent) and analysed.

- The frequency and distribution of the parameters was done alongside their analysis with mean and standard deviations, chi-square test and odds ratio as well as univariate analysis and multivariate regression analysis. The Statistical significance was inferred when $\mathrm{p}$ value $<0.05$. Statistical analysis was carried out using standard formulae. The usage of Microsoft Excel and SPSS (statistical package for social science) software was done for the purpose of data entry and analysis.

\section{Results}

\begin{tabular}{|c|c|c|c|c|}
\hline \multicolumn{3}{|c|}{ Characteristics of the study sample } & $\mathbf{f}$ & $\%$ \\
\hline \multirow{5}{*}{\multicolumn{2}{|c|}{ Age (Years) }} & $<18$ Years & 7 & 5.8 \\
\hline & & 18-25 Years & 49 & 40.8 \\
\hline & & 26-40 Years & 29 & 24.2 \\
\hline & & 41-60 Years & 23 & 19.2 \\
\hline & & $>60$ Years & 12 & 10.0 \\
\hline \multirow{2}{*}{\multicolumn{2}{|c|}{ Gender }} & Male & 75 & 62.5 \\
\hline & & Female & 45 & 37.5 \\
\hline \multirow{5}{*}{\multicolumn{2}{|c|}{ Chief Complaints }} & Fever & 117 & 97.5 \\
\hline & & Headache & 103 & 85.8 \\
\hline & & Vomiting & 98 & 81.7 \\
\hline & & Altered Sensorium & 98 & 81.7 \\
\hline & & Seizures & 22 & 18.3 \\
\hline \multirow{4}{*}{\multicolumn{2}{|c|}{ Duration of Symptom ( In days) }} & 10 & 28 & 23.3 \\
\hline & & $10-15$ & 29 & 24.2 \\
\hline & & $16-30$ & 35 & 29.2 \\
\hline & & $>30$ & 28 & 23.3 \\
\hline \multirow{4}{*}{$\begin{array}{l}\text { Personal } \\
\text { History }\end{array}$} & \multirow{2}{*}{ Smoking } & Smokers & 22 & 18.3 \\
\hline & & Non-smokers & 98 & 81.7 \\
\hline & \multirow[t]{2}{*}{ Alcoholism } & Alcoholic & 10 & 8.3 \\
\hline & & Non-Alcoholic & 110 & 91.7 \\
\hline \multicolumn{3}{|c|}{ Sample Characteristics } & $\mathrm{f}$ & $\%$ \\
\hline \multirow{12}{*}{$\begin{array}{l}\text { Past } \\
\text { Medical } \\
\text { History }\end{array}$} & \multirow[t]{2}{*}{ Hypertension } & Yes & 4 & 3.3 \\
\hline & & No & 116 & 96.7 \\
\hline & \multirow[t]{2}{*}{ Diabetes } & Yes & 4 & 3.3 \\
\hline & & No & 116 & 96.7 \\
\hline & \multirow[t]{2}{*}{ Tuberculosis } & Yes & 16 & 13.3 \\
\hline & & No & 104 & 86.7 \\
\hline & \multirow{2}{*}{$\begin{array}{l}\text { Cerebrovascular } \\
\text { Accident }\end{array}$} & Yes & 04 & 3.3 \\
\hline & & No & 116 & 96.7 \\
\hline & \multirow[t]{2}{*}{ Others } & Yes & 16 & 13.3 \\
\hline & & No & 104 & 86.7 \\
\hline & \multirow{2}{*}{$\begin{array}{l}\text { Extra-neural } \\
\text { Tuberculosis }\end{array}$} & Yes & 23 & 19.1 \\
\hline & & No & 97 & 80.9 \\
\hline
\end{tabular}

The data that has been presented in the [Table 1] shows majority $(40.8 \%)$ of the cases constituting the sample in our study were in the group belonging to ages of 18-25 years, most $(62.5 \%)$ of them were males, about $81.7 \%$ sample having a chief complaint of altered sensorium, around $29.2 \%$ of them were having duration of symptoms (In days) between 16-30 days. Regarding their personal history around $18.3 \%$ were smokers and about $8.3 \%$ of them were alcoholics.

Regarding past medical history, $3.3 \%$ of sample have hypertension, $3.3 \%$ have diabetes, about $13.3 \%$ of them had history of Tuberculosis, $3.3 \%$ of them have history of cerebrovascular accidents and $19.1 \%$ of them had extraneural tuberculosis.

Table 2: Average value of Sample Characteristics ( $N=120)$

\begin{tabular}{|l|l|}
\hline Sample Characteristics & Average \\
\hline Age in Years & $34.85 \pm 17.02$ \\
\hline Duration of Symptom ( In days) & $29.63 \pm 30.5$ \\
\hline Duration of Symptom (In days) & Median (19.0) and Range (176) \\
\hline
\end{tabular}


Table 3: MRC TBM stages of patients being shown with their numbers and percentages $(\mathrm{N}=120)$

\begin{tabular}{|l|l|}
\hline MRC TBM stages & Frequency (\%) \\
\hline Stage 1 & $10(8.3)$ \\
\hline Stage 2 & $66(55.0)$ \\
\hline Stage 3 & $44(36.7)$ \\
\hline
\end{tabular}

The findings of the TBM stage of patients on their presentation in [Table 3] shows that $8.3 \%$ of them were in the MRC TBM stage 1, 55.0\% of them in the MRC TBM stage 2 and $36.7 \%$ of them in MRC TBM stage 3.

Table 4: Barthel Index (Outcome) of patients with their number and percentages $(\mathrm{N}=120)$

\begin{tabular}{|l|l|l|}
\hline Diagnosis & f & \% \\
\hline Good & 73 & 60.8 \\
\hline Poor & 36 & 30.0 \\
\hline Mortality/Death & 11 & 9.2 \\
\hline
\end{tabular}

Table 5: Association between sample characteristics with outcome ( $\mathrm{N}=120)$

\begin{tabular}{|c|c|c|c|c|c|}
\hline \multirow[t]{2}{*}{$\begin{array}{l}\text { Sample } \\
\text { characteristics }\end{array}$} & \multicolumn{2}{|c|}{$\begin{array}{l}\text { Outcome (Barthel } \\
\text { Index) }\end{array}$} & \multirow[t]{2}{*}{$\mathrm{X}^{2}$} & \multirow[t]{2}{*}{ df } & \multirow[t]{2}{*}{$\begin{array}{l}\mathbf{p} \\
\text { value }\end{array}$} \\
\hline & Good & Poor & & & \\
\hline \multicolumn{6}{|l|}{ Age in years } \\
\hline$<18$ Years & 4 & 3 & \multirow{5}{*}{5.201} & \multirow{5}{*}{4} & \multirow{5}{*}{0.267} \\
\hline $18-25$ Years & 33 & 16 & & & \\
\hline 26-40 Years & 20 & 9 & & & \\
\hline 41-60 Years & 11 & 12 & & & \\
\hline$>60$ Years & 5 & 7 & & & \\
\hline \multicolumn{6}{|l|}{ Gender } \\
\hline Male & 43 & 32 & \multirow[t]{2}{*}{1.028} & \multirow[t]{2}{*}{1} & \multirow[t]{2}{*}{.311} \\
\hline Female & 30 & 15 & & & \\
\hline \multicolumn{6}{|l|}{ Chief Complaints } \\
\hline \multicolumn{6}{|l|}{ Fever } \\
\hline Yes & 71 & 46 & \multirow[t]{2}{*}{.044} & \multirow[t]{2}{*}{1} & \multirow[t]{2}{*}{.834} \\
\hline No & 2 & 1 & & & \\
\hline \multicolumn{6}{|l|}{ Headache } \\
\hline Yes & 64 & 39 & \multirow[t]{2}{*}{.518} & \multirow[t]{2}{*}{1} & \multirow[t]{2}{*}{.472} \\
\hline No & 9 & 8 & & & \\
\hline \multicolumn{6}{|l|}{ Vomiting } \\
\hline Yes & 63 & 35 & \multirow[t]{2}{*}{2.674} & 1 & .102 \\
\hline No & 10 & 12 & & & \\
\hline Altered Sensoriur & & & & & \\
\hline Yes & 56 & 42 & 3.056 & 1 & .080 \\
\hline No & 17 & 5 & & & \\
\hline Seizures & & & & & \\
\hline Yes & 8 & 14 & 6.770 & 1 & $.009 *$ \\
\hline No & 65 & 33 & & & \\
\hline $\begin{array}{l}\text { Duration of Symp } \\
\text { (In days) }\end{array}$ & & & & & \\
\hline$<10$ & 21 & 7 & 13.269 & 3 & $.004 *$ \\
\hline $10-15$ & 23 & 6 & & & \\
\hline $16-30$ & 18 & 17 & & & \\
\hline$>30$ & 11 & 17 & & & \\
\hline Smoking & & & & & \\
\hline Smokers & 12 & 10 & .447 & 1 & .504 \\
\hline Non-smokers & 61 & 37 & & & \\
\hline Alcoholism & & & & & \\
\hline Alcoholic & 5 & 5 & .537 & 1 & .464 \\
\hline Non-Alcoholic & 68 & 42 & & & \\
\hline Tuberculosis & & & & & \\
\hline Yes & 9 & 7 & .163 & 1 & .687 \\
\hline No & 64 & 40 & & & \\
\hline $\begin{array}{l}\text { Cerebro Vascular } \\
\text { Accidents }\end{array}$ & & & & & \\
\hline Yes & 0 & 4 & 6.427 & 1 & $.011 *$ \\
\hline No & 73 & 43 & & & \\
\hline
\end{tabular}

The Barthel Index of patients in the table shows that around $60.8 \%$ of them had good outcome, $30.0 \%$ of them had poor outcome and $9.2 \%$ of them had death as outcome. [Table 4] [Table 5] depicts that there is a statistically significant association between sample characteristics with outcome, like duration of symptoms $(\mathrm{p}=0.004)$, chief complaints of seizures $(\mathrm{p}=0.004)$, and history of cerebro- vascular accidents $(\mathrm{p}=0.011)$.

Table 6: Association between fundus findings with outcome $(\mathrm{N}=120)$

\begin{tabular}{|l|l|l|l|l|l|}
\hline \multirow{2}{*}{} & \multicolumn{2}{|l|}{$\begin{array}{l}\text { Outcome } \\
\text { (Barthel Index) }\end{array}$} & \multirow{2}{*}{$\mathbf{X}^{2}$} & df & $\begin{array}{l}\text { p } \\
\text { value }\end{array}$ \\
\cline { 2 - 3 } & Good & Poor & & & \\
\hline Fundus & & & & & \\
\hline Normal & 66 & 24 & 23.846 & 3 & $0.001^{*}$ \\
\hline Early signs of papilledema & 6 & 19 & & & \\
\hline Papilledema & 1 & 3 & & & \\
\hline Frank Papilledema & 0 & 1 & & & \\
\hline
\end{tabular}

${ }^{*} \mathrm{p}>0.5$ (level of significance)

[Table 6] depicts that there is a statistically significant association between Fundus findings and outcome $(p=0.01)$.

Table 7: Association between blood Investigations (parameters) with outcome $(\mathrm{N}=120)$

\begin{tabular}{|l|l|l|l|l|l|}
\hline \multirow{2}{*}{ Investigations } & \multicolumn{2}{l}{$\begin{array}{l}\text { Outcome (Barthel } \\
\text { Index) }\end{array}$} & \multirow{2}{*}{ X2 } & df & $\begin{array}{l}\text { p } \\
\text { value }\end{array}$ \\
\cline { 2 - 3 } & Good & Poor & & & \\
\hline Hemoglobin g/dl & & & & & \\
\hline$<10 \mathrm{~g} / \mathrm{dl}$ & 9 & 8 & .518 & 1 & .472 \\
\hline 10 and above $10 \mathrm{~g} / \mathrm{dl}$ & 64 & 39 & & & \\
\hline TLC cells/cu mm & & & & & \\
\hline$<9000$ cells/cu mm & 44 & 16 & 7.869 & 1 & $0.005^{*}$ \\
\hline$>9000$ cells/cu mm & 29 & 31 & & & \\
\hline ESR mm/hr & & & & & \\
\hline$<20 \mathrm{~mm} / \mathrm{hr}$ & 2 & 0 & 1.309 & 1 & .252 \\
\hline$>20 \mathrm{~mm} / \mathrm{hr}$ & 71 & 47 & & & \\
\hline Urea md/dl & & & & & \\
\hline$<40 \mathrm{mg} / \mathrm{dl}$ & 46 & 27 & $.372 \mathrm{a}$ & 1 & .542 \\
\hline$>40 \mathrm{mg} / \mathrm{dl}$ & 27 & 20 & & & \\
\hline Sodium meq/L & & & & & \\
\hline Sodium <135 meq/L & 49 & 23 & 3.941 & 1 & $0.04^{*}$ \\
\hline Sodium $>135 \mathrm{meq} / \mathrm{L}$ & 24 & 24 & & & \\
\hline Potassium meq/L & & & & & \\
\hline$<3.5 \mathrm{meq} / \mathrm{L}$ & 15 & 16 & 6.988 & 2 & $0.03^{*}$ \\
\hline $3.5-5.0 \mathrm{meq} / \mathrm{L}$ & 56 & 26 & & & \\
\hline$>5.0 \mathrm{meq} / \mathrm{dl}$ & 2 & 5 & & & \\
\hline Serum Albumin & & & & & \\
\hline$<3.5 \mathrm{mg} / \mathrm{dl}$ & 10 & 17 & 8.280 & 1 & $0.004^{*}$ \\
\hline$>3.5 \mathrm{mg} / \mathrm{dl}$ & 63 & 30 & & & \\
\hline *p $>0.5$ (level of significance) & & & & & \\
\hline
\end{tabular}

[Table 7] depicts that there is a statistically significant association between blood Investigations (parameters) with outcome, like TLC cells/cu mm ( $\mathrm{p}=0.005)$, Sodium meq/L $(\mathrm{p}=0.04)$, Potassium meq/L $(\mathrm{p}=0.03)$ and Serum Albumin $(\mathrm{p}=0.004)$

[Table 8] depicts that there is a statistically significant association between CSF analysis with outcome, like CSF Glucose $\mathrm{mg} / \mathrm{dl}(\mathrm{p}=0.03)$

[Table 9] depicts that there is a statistically significant association between CT/MRI findings and MRC TBM stages with outcome, like hydrocephalus $(\mathrm{p}=0.001)$, infarcts $(\mathrm{p}=0.001)$, tuberculomas $(\mathrm{p}=0.02)$ and MRC TBM stages 
$(\mathrm{p}=0.001)$

Table 8: Association between CSF analysis with outcome (N=120)

\begin{tabular}{|c|c|c|c|c|c|}
\hline \multirow[t]{2}{*}{ Investigations } & \multicolumn{2}{|c|}{$\begin{array}{l}\text { Outcome (Barthel } \\
\text { Index) }\end{array}$} & \multirow[t]{2}{*}{$x^{2}$} & \multirow[t]{2}{*}{ df } & \multirow[t]{2}{*}{$\begin{array}{l}\mathbf{p} \\
\text { value }\end{array}$} \\
\hline & Good & Poor & & & \\
\hline \multicolumn{6}{|l|}{ CSF Protein $\mathrm{mg} / \mathrm{dl}$} \\
\hline$<100 \mathrm{mg} / \mathrm{dl}$ & 12 & 6 & \multirow{2}{*}{.302} & \multirow[t]{2}{*}{1} & \multirow{2}{*}{.582} \\
\hline$>100 \mathrm{mg} / \mathrm{dl}$ & 61 & 41 & & & \\
\hline \multicolumn{6}{|l|}{ CSF Glucose $\mathrm{mg} / \mathrm{dl}$} \\
\hline$<50 \mathrm{mg} / \mathrm{dl}$ & 44 & 19 & \multirow[t]{2}{*}{4.51} & \multirow[t]{2}{*}{1} & \multirow{2}{*}{$0.03^{*}$} \\
\hline$>50 \mathrm{mg} / \mathrm{dl}$ & 29 & 28 & & & \\
\hline \multicolumn{6}{|c|}{ CSF TLC cells/cu mm } \\
\hline$<150 \mathrm{Cell} / \mathrm{cu} \mathrm{mm}$ & 56 & 37 & \multirow{3}{*}{.066} & \multirow{3}{*}{1} & \multirow{3}{*}{.797} \\
\hline$>150 \mathrm{Cell} / \mathrm{cu} \mathrm{mm}$ & 17 & 10 & & & \\
\hline \multicolumn{3}{|l|}{ CSF ADA IU/dl } & & & \\
\hline$<9.5 \mathrm{IU} / \mathrm{dl}$ & 17 & 9 & \multirow[t]{2}{*}{.289} & \multirow[t]{2}{*}{1} & \multirow[t]{2}{*}{.591} \\
\hline$>9.5 \mathrm{IU} / \mathrm{dl}$ & 56 & 38 & & & \\
\hline
\end{tabular}

Table 9: Association between CT/MRI findings and MRC TBM stages with outcome $(\mathrm{N}=120)$

\begin{tabular}{|c|c|c|c|c|c|}
\hline & \multicolumn{2}{|c|}{$\begin{array}{l}\text { Outcome (Barthel } \\
\text { Index) }\end{array}$} & \multirow[t]{2}{*}{$x^{2}$} & \multirow[t]{2}{*}{ df } & \multirow[t]{2}{*}{$\begin{array}{l}\mathbf{p} \\
\text { value }\end{array}$} \\
\hline & Good & Poor & & & \\
\hline \multicolumn{6}{|l|}{ CT/MRI } \\
\hline \multicolumn{6}{|c|}{ Hydrocephalus } \\
\hline Yes & 4 & 20 & \multirow[t]{2}{*}{24.561} & \multirow[t]{2}{*}{1} & \multirow[t]{2}{*}{$0.001 *$} \\
\hline No & 69 & 27 & & & \\
\hline \multicolumn{6}{|c|}{$\begin{array}{l}\text { Meningeal } \\
\text { Enhancement }\end{array}$} \\
\hline Yes & 11 & 12 & \multirow[t]{2}{*}{2.020} & \multirow[t]{2}{*}{1} & \multirow[t]{2}{*}{0.155} \\
\hline No & 62 & 35 & & & \\
\hline \multicolumn{6}{|l|}{ Infarcts } \\
\hline Yes & 8 & 22 & \multirow[t]{2}{*}{19.598} & \multirow[t]{2}{*}{1} & \multirow[t]{2}{*}{$0.001 *$} \\
\hline No & 65 & 25 & & & \\
\hline \multicolumn{6}{|c|}{ Tuberculomas } \\
\hline Yes & 11 & 15 & \multirow[t]{2}{*}{4.781} & \multirow[t]{2}{*}{1} & \multirow[t]{2}{*}{$0.02 *$} \\
\hline No & 62 & 32 & & & \\
\hline \multicolumn{6}{|c|}{ MRC TBM stages } \\
\hline Stage 1 & 10 & 0 & \multirow{3}{*}{92.592} & \multirow{3}{*}{2} & \multirow{3}{*}{$0.001 *$} \\
\hline Stage 2 & 61 & 5 & & & \\
\hline Stage 3 & 2 & 42 & & & \\
\hline
\end{tabular}

$* \mathrm{p}>0.5$ (level of significance)

\section{Discussion}

Tuberculosis continues to remain a highly infectious disease that is still widespread in our nation. The current study was performed in patients presenting to TMMC \& RC to study clinical features, complications and predictors of morbidity and mortality. All patients' history was taken in a detailed and comprehensive manner from the patient or their attendants to include all demographic and personal details of the patient. This was followed by meticulous evaluation of the patient's clinical features and examination. Routine lab investigations, CSF evaluation along with neuroimaging NCCT/MRI brain and chest x-ray were done. All patients or attendant's consents after giving full information in a written manner were taken for patient enrolment into the study.

In the current study a total of 120 patients were enrolled including $75(62.5 \%)$ males and $45(37.5 \%)$ females. The mean age of the population in the study was $34.85 \pm 17.02$ years. Poor outcome was seen in $39.8 \%$ of the patients amongst which 11 patients expired and 36 had Barthel's index $<12$.

With regards to the mean age of the patients in our study, it was viewed to be similar to other studies done in our country where the mean was around 37 years, this was widely different from the study in Taiwan $(54.9 \pm 18$.6years $)$ by Po Chang Hsu et al. ${ }^{[10]}$ The age being lesser in our nation's studies can be attributed to the inclusion of children or patient 12 years or older due to the greater incidence in childhood of TBM. In our study all diagnosed cases of TBM presenting to us were included, with the youngest patient being 14 years old and the oldest being 80 years. Nevertheless, all studies exhibited slightly greater male preponderance. The $62.5 \%$ prevalence of males in our study was comparable to the $61.8 \%$ prevalence in the north Indian study by Kaur et al. ${ }^{[1]}$ The age of the patients in or study did not have a statistically significant association with poor outcome $(\mathrm{p}=0.267)$ in univariate analysis.

Table 10: Comparison of demographic and clinical features of tuberculous meningitis patients in present study group with those of other studies

\begin{tabular}{|l|l|l|l|l|}
\hline Variables & Po-ChangHsu et al 2010 & Hakan et al 2014 & Kaur et al 2015 & Present study 2017 \\
\hline Age(years) Mean \pm SD & $54.9 \pm 18.6$ & $37.25 \pm 11.67$ & $36.42 \pm 16.20$ & $34.85 \pm 17.02$ \\
\hline Gender: & $71(65.7 \%)$ & $266(52.46 \%)$ & $34(61.8 \%)$ & $75(62.50 \%)$ \\
Male & $27(34.3 \%)$ & $241(47.54 \%)$ & $21(38.2 \%)$ & $45(37.50 \%)$ \\
Female & & & & \\
\hline Clinical features Headache & $65(60.2 \%)$ & -- & $40(72.7 \%)$ & $103(85.80 \%)$ \\
Vomiting & $19(20.3 \%)$ & $281(55.4 \%)$ & $30(54.5 \%)$ & $98(81.70 \%)$ \\
Altered sensorium & $68(63.0 \%)$ & $58(11.44 \%)$ & $36(65.5 \%)$ & $98(81.70 \%)$ \\
\hline Seizures & $15(13.9 \%)$ & $69(13.6 \%)$ & $8(23.6 \%)$ & $22(18.3 \%)$ \\
Paresis & $2(1.8 \%)$ & - & - & \\
\hline Clinical signs Papilledema & - & $81(15.9 \%)$ & $8(14.5 \%)$ & $30(8.33 \%)$ \\
Cranial nerve palsy & - & $69(13.6 \%)$ & $8(14.5 \%)$ & $9(7.5 \%)$ \\
Hemiparesis & $2(1.8 \%)$ & & $8(6.67 \%)$ \\
\hline
\end{tabular}

Amongst the clinical features, fever was most common, found in almost all the patients $(97.5 \%)$. It was followed by headache $85.8 \%$ then vomiting and altered sensorium $81.7 \%$ each, followed by seizures $18.3 \%$ and lastly paresis in $16.63 \%$. These findings were comparable to other studies having fever as the commonest symptom followed by headache, vomiting and seizures. Our study included patients with characteristic clinical features of TBM and with the patients presenting to us late, altered sensorium was found in relatively higher number of patients in comparison to the 
observation of features such as headache (72.7\%), altered sensorium $(65.5 \%)$ vomiting $(54.5 \%)$, seizure $(23.6 \%)$ and paresis $(14.5 \%)$ being the commonest in the study by Kaur et al. ${ }^{[11]}$ Another study exhibited altered sensorium being the commonest with $76.9 \%$ cases, with headache $59.6 \%$, vomiting $36.5 \%$, focal weakness in $19 \%$ and seizures $11.5 \%$ being the other features in the study orchestrated by Salekeen et al. ${ }^{[12]}$ Fever was an essential component in almost all of these studies. In our study patients with seizure had significantly greater chances of poor outcome while other clinical features were not significant although the lowered sensorium with the overall poor patient condition and stage was somewhat more common in patients with poor outcome. In our study amongst the clinical signs we observed papilledema in 25 percent of the patients and cranial nerve palsies in $7.5 \%$ cases with 6th cranial nerve involved in all the cases. The observation of $\mathrm{CN}$ palsies in previous studies have been shown to occur in $20-30 \%$ cases with most frequently affected being the 6th $\mathrm{CN} .{ }^{[7,13,14]} \mathrm{A}$ difference from our study which had somewhat lesser percentage of patients with cranial nerve palsies, while the incidence in a study by Gupta et al, ${ }^{[15]}$ was $23.5 \%$. All the patients in our study had signs of meningeal irritation while in most studies it was around $60-70 \%$ which can also be due to the greater number of patients presenting in our study with altered sensorium-81.7\%. Abbas et al, ${ }^{[16]}$ in their study in north India at a tertiary care centre noted papilledema in $22.2 \%$ cases, with Salekeen et al, ${ }^{[17]}$ noting similar incidence in $19.2 \%$ which was corresponding to the incidence in our study of $25 \%$. One patient in our study had tubercular brain abscess and one patient had pituitary apoplexy secondary to TBM.

Our study had a mean duration of symptoms of $29.63 \pm 30.5$ days and majority of the patients reported between 16-30 days $(29.2 \%)$ followed by $10-15$ days $(24.2 \%)$ and an equal number between less than 10 and more than 30 days $(23.3 \%$ each). The duration in our study was defined on the basis of time of onset of symptoms till the time of admission of the patient. Hakan et al, ${ }^{[18]}$ in 2015 in the Hydarpasa II study ascertained a mean symptom duration of 20 days alongside 10 and 30 interquartile range. In the Indian study the duration had a range of 8 to 30 days with a mean of $42.7 \pm 62.3$ days as discerned by Gupta et al. ${ }^{[15]}$ The delayed presentation with a long duration of symptoms is credited to no specific test being available for the rapid diagnosis of TBM and the symptoms pertaining to the disease also not being highly specific. Greater duration of symptoms in our study was associated with a poor outcome ( $\mathrm{p}$ value $=0.004$ ).

The patients in the study were classified based on the MRC staging. In our study the highest number of patients were in stage $2(66 / 120)$ about $55 \%$ cases followed by stage 3 (44/120) $36.7 \%$ cases and finally stage 1 (10/120) $8.3 \%$ cases, which were comparable to other studies. Such as Kaur et al, ${ }^{[1]}$ noted $50.9 \%$ in stage 2 followed by $36.7 \%$ in stage 3 and finally $12.7 \%$ in stage 1 . Similarly, Chang Hsu et al, ${ }^{[19]}$ noted $51.9 \%$ cases in stage 2 followed by $25.9 \%$ in stage 3 and finally $22.2 \%$ in stage 1 . An interpretation of stage 2 being the commonest stage of presentation is obvious in all these studies. Nonetheless all these studies were retrospective in nature and this study was done prospectively having high clinical conjecture for TBM. Still the patients that had presented to us were in late stages of the disease, after having developed altered sensorium and being referred from other centres after deterioration or with complications. Stage of the disease had significant association with prognosis in our study ( $\mathrm{p}$ value $=0.001$ ).

Patients were also investigated for evidence of extra neural sites of TB with all patients having a chest $\mathrm{x}$-ray and few requiring other investigations if deemed necessary. In our study $23 / 120$ around $19.17 \%$ patients had evidence of extra neural TB. In other studies, it has usually been reported to be around 18 to $30 \%$. The most common site for extra neural TB was pulmonary TB with the others being 1 patient with intestinal TB and 1 patient with tubercular lymphadenitis. Amongst the various comorbidities 4 patients had diabetes mellitus, 4 had hypertension and 4 had previous episodes of stroke. 8 patients were positive for hepatitis C, 3 were HIV positive and 1 was HBsAg positive. The symptoms of HIV positive patients were similar to HIV negative patients although they have higher frequency of extra neural TB as earlier reported. ${ }^{[20]}$ The presence of extra neural TB along with greater stage of the disease and baseline modified Barthel index $<12$ were found to be associated with poor outcomes in a prospective study by R.Ingole et al. ${ }^{[21]}$

The past studies were utilized to recognize and evaluate the factors which served as poor prognostic markers and their prognostic values were equivalent to $2 / 3$ rd of serum. Thus these findings were comparable to various studies. ${ }^{[22,23]}$ The CSF ADA had a median of $12 \mathrm{U} / \mathrm{L}$ while mean values being $14.4 \pm 6.9 \mathrm{U} / \mathrm{L}$ and $9.6 \pm 4.1 \mathrm{U} / \mathrm{L}$ in studies by Kaur et al, ${ }^{[11]}$ and Gambhir et al, ${ }^{[24]}$ Anemia $\mathrm{Hb}<10 \mathrm{gm} / \mathrm{dl}$ was observed in $14.2 \%$ cases which was lesser than other studies. ${ }^{[12,2]}$ Hyponatremia was seen in $60 \%$ of the patients which was comparable to other studies. ${ }^{[9,26-29]}$ Hypokalemia was observed in $25.8 \%$ patients. Hypoalbuminemia was observed in $22.5 \%$ patients. All 3 of these parameters hyponatremia (p value $=0.04), \quad$ hypokalemia $(\mathrm{p} \quad$ value $=0.03)$ and hypoalbuminemia ( $\mathrm{p}$ value $=0.004)$ had significant association with poor outcome. Amongst these cases hyponatremia can be occurring due to cerebral salt wasting or SIADH as the commonest causes. Hypokalemia usually seen secondary to diuretic therapy in TBM for raised ICT but can be hypothesized to be occurring as a result of decreased intake in altered and malnourished patients along with recurrent vomiting. While hypoalbuminemia can be also due to malnutrition in patients with TBM, the other causes may include infection and inflammation. Further studies evaluating their role maybe needed to evaluate their roles and significance and to rule out incidental findings and confounding factors leading to association.

Neuroimaging (CT/MRI Brain) exhibited infarcts in $25 \%$ patients, tuberculoma in $21.7 \%$, along with hydrocephalus in $20 \%$ and meningeal enhancement in $19.2 \%$. But in most other studies hydrocephalus was the most prevalent finding. ${ }^{[11,12,18,30]}$ Christensen et al, ${ }^{[23]}$ viewed hydrocephalus in $29 \%$ cases, along with infarcts in $29 \%$ and followed by tuberculoma in $14 \%$ cases. David et al, ${ }^{[31]}$ also viewed tuberculoma in $14 \%$ cases. The frequent reported prevalence of infarcts on CT was 20.5 to $38 \%$, nevertheless infarctions are observed with greater prevalence on MRI in comparison to $\mathrm{CT} \cdot{ }^{[32]}$ Kee et al, ${ }^{[30]}$ visualized hydrocephalus in $43.33 \%$, 
infarcts-21.7\%, meningeal enhancement $-20 \%$ and finally tuberculoma in $5 \%$ cases.

\section{Predictors of Poor Outcome}

A total of 47 out of 120 patients had a poor outcome amongst which 11 patients expired while 36 patients had Barthel's index $<12$. The overall mortality is $9.2 \%$ which is profoundly lesser in comparison to mortality of $19-67 \%$ reported in other studies. Additionally, it was recognized that residual neurological disability as a result of hemiparesis or deficit due to $\mathrm{CN}$ palsy persisted in certain patients but not all of these patients had a Barthel index $<12$. The lesser mortality in our study can be due to different factors. One of which was the greater clinical suspicion to recognize TBM that lead to quicker diagnosis and management even with non-specific presentation of fever accompanied by headache and vomiting. Another factor was the initiation of the recommended regime and counselling of patient and attendants to ensure strict adherence. Additionally, strict implementation of measures and recommendations to manage raised intracranial pressure were followed.

Univariate analysis exhibited that duration of symptoms $(\mathrm{p}=0.004)$, certain clinical symptoms (seizure, $\mathrm{p}=0.009$ ), past history of CVA ( $\mathrm{p}=0.011)$ and Stage of TBM on admission $(\mathrm{p}=0.001)$ were associated with poor outcome. The other factors that were associated with poor outcome include papilledema $(\mathrm{p}=0.001)$, hyponatremia $(\mathrm{p}=0.03)$, hypokalemia $(\mathrm{p}=0.04)$, hypoalbuminemia $(\mathrm{p}=0.004), \quad$ CSF glucose $<50$ $\mathrm{mg} / \mathrm{dl} \quad(\mathrm{p}=0.03), T L C>9000 \quad(\mathrm{p}=0.005)$, and neuroimaging parameters such as hydrocephalus $(\mathrm{p}=0.001)$, infarcts $(\mathrm{p}=0.001)$ and tuberculoma $(\mathrm{p}=0.02)$.

\begin{tabular}{|c|c|c|c|}
\hline Table 11: Determinan & Goo & poc & \\
\hline Factors & $\mathbf{B}$ & p-value & Adjusted OR \\
\hline Age in Years & 0.02 & 0.04 & 1.02 \\
\hline MRC Stage 1* & 1 & 0.001 & 1 \\
\hline MRC Stage 2 & -24.60 & 0.998 & 0.1 \\
\hline MRC Stage 3 & -5.51 & 0.001 & 0.4 \\
\hline TLC $>9000$ & -1.07 & 0.006 & 0.34 \\
\hline $\begin{array}{l}<10 \text { Days duration of } \\
\text { symptoms* }\end{array}$ & 1 & 0.002 & 1 \\
\hline 10-15 days duration & -2.43 & 0.851 & 0.78 \\
\hline 16-30 days of duration & -1.22 & 0.380 & 0.29 \\
\hline$>30$ days of duration & 1.03 & 0.417 & 2.80 \\
\hline Meningeal Enhancement & -2.06 & 0.176 & 0.12 \\
\hline Hydrocephalus & 2.65 & 0.04 & 14.16 \\
\hline Infarcts & 1.31 & 0.31 & 3.71 \\
\hline Tuberculoma & 1.62 & 0.231 & 1.02 \\
\hline Hyponatremia & 0.81 & 0.04 & 0.44 \\
\hline Hypokalemia & 0.69 & 0.13 & 1.99 \\
\hline Hypoalbuminemia & 1.29 & 0.007 & 3.65 \\
\hline Low CSF Glucose & -0.97 & 0.01 & 0.37 \\
\hline
\end{tabular}

Multivariate logistic regression analysis of these factors revealed age $(\mathrm{p}=0.04)$, duration of symptoms $(\mathrm{p}=0.002)$, stage of TBM on presentation $(\mathrm{p}=0.001)$, TLC $>9000$ $(\mathrm{p}=0.006)$, low CSF glucose $(\mathrm{p}=0.01)$, hyponatremia $(\mathrm{p}=0.04)$, hypoalbuminemia $(\mathrm{p}=0.007)$ and hydrocephalus $(\mathrm{p}=0.04)$ on neuroimaging were significant risk factors of mortality and morbidity in adult patients of TBM. Thus from the following table it can also be inferred that the variables age, stage of TBM on presentation, duration of symptoms, hypokalemia, hypoalbuminemia and neuroimaging suggestive of hydrocephalus, infarcts and tuberculoma were more likely to have poor prognosis with adjusted odds ratio more than or equal to 1 .

\section{Conclusion}

In the prospective study orchestrated among 120 patients with TBM at TMMC\&RC, Moradabad based on the observations made, epidemiological data was collected and assessment of predictors of morbidity and mortality was performed. It is study done on relatively smaller group of subjects and is a preliminary study with a shorter duration of follow up. Studies done at multiple centres with greater number of subjects and longer follow up may aid in better analysis of the disease and the correlated determinants. Also studies aimed at certain parameters like hypoalbuminemia maybe be required to analyze their true significance. The current study may provide components for the composition of a score to predict outcome using duration of symptoms, MRC staging, age of the patient, presence of papilledema, neuroimaging suggestive of hydrocephalus and lab investigations such as raised TLC, hyponatremia, hypoalbuminemia and low CSF glucose. This can be utilised for prompt employment of rigorous management remedies in order to save patients' life.

\section{References}

1. TB disease burden. Global Tuberculosis Report. (C) World Health Organization 2019: Chapter3:P.No.27. https://apps.who.int/iris/bitstream/handle/10665/329368/978924156571 4-eng.pdf?ua $=1$ [Accessed 6th December 2019]

2. Gu J, Xiao H, Wu F, Ge Y, Ma J, Sun W. Prognostic factors of tuberculous meningitis: a single-center study. Int J ClinExp Med 2015;8:4487-93.

3. Girgis N I,Sultan Y, Farid Z. Tuberculous meningitis, Abbassia Fever Hospital-U.S. Naval Medical Research Unit No. 3-Cairo, Egypt, from 1976 to 1996. Am J Trop Med Hyg 1998;58:28-34.

4. Rock RB, Hu S, Gekker G. Mycobacterium tuberculosis-induced cytokine and chemokine expression by human microglia and astrocytes: effects of dexamethasone. J Infect Dis 2005;192:2054-8.

5. Verdon R, Chevret S, Laissy JP, Wolff M. Tuberculous meningitis in adults review of 48 cases. Clin Infect Dis 1996;22,982-8.

6. Kent SJ, Crowe SM, Yung A, Lucas CR, Mijch AM. Tuberculous meningitis: a 30-year review. Clin Infect Dis 1993;17:987-94.

7. Bidstrup C, Andersen PH, Skinhøj P, Andersen AB. Tuberculous meningitis in a country with a low incidence of tuberculosis: still a serious disease and a diagnostic challenge. Scandinavian J Infect Dis 2002;34:811-4.

8. Council MR. Streptomycin treatment of pulmonary tuberculosis. British Medical Journal. 1948 Oct;2:769-82.

9. Misra UK et al. A study of hyponatremia in tuberculous meningitis. J NeurolSci .2016;367:152-7

10. Po-Chang H, Chien CY, Jung Jr Y, Po-Yen H, Ping CC, Ming HL. Prognostic factors of tuberculous meningitis in adults: a 6-year retrospective study at a tertiary hospital in Northern Taiwan. J MicrobiolImmunol Infect 2010; 43:111-8.

11. Kaur H, Sharma K, Modi M, Sharma A, Rana S, Khandelwal N, et al. Prospective analysis of 55 cases of tuberculosis meningitis (TBM) in North India. J ClinDiag Res 2015; 9:15-9.

12. Salekeen S, Mahmood K, Naqvi H. et al. Clinical course, complications and predictors of mortality in patients with tuberculous meningitis - an experience of fifty two cases at Civil Hospital Karachi, Pakistan JPMA.2013;63:563.

13. Sabbatani S. Historical insights into tuberculosis. GirolamoFracastoro's intuition on the transmission of tuberculosis and his opponents. History of an idea. Infez Med. 2004;12(4):284-291. 


\section{Malik \& Singh: Clinical Carrelates of Jubercular Meningitis}

14. O'Connor TM. Reference Module in Biomedical Sciences, from International Encyclopedia of Public Health. New York, NY: Elsevier; 2008. Tuberculosis: overview; pp. 408-414.

15. Gupta R et al. Predictors of adverse outcome in patients of tuberculous meningitis in a multi-centric study from India. Indian $\mathrm{J}$ Tuberc. 2017;185:1-6.

16. Abbas A et al. Visual Impairment in HIV Negative Tuberculosis Meningitis. J Meningitis 2015;1:1

17. Verdon R, Chevret S, Laissy JP, Wolff M. Tuberculous meningitis in adults review of 48 cases. Clin Infect Dis 1996;22,982-8.

18. Erdem, H., Ozturk-Engin, D., Tireli, H et al. Hamsi scoring in the prediction of unfavorable outcomes from tuberculous meningitis: results of Haydarpasa-II study. Journal of Neurology 2015; 262:890-898.

19. Po-Chang H, Chien CY, Jung Jr Y, Po-Yen H, Ping CC, Ming HL. Prognostic factors of tuberculous meningitis in adults: a 6-year retrospective study at a tertiary hospital in Northern Taiwan. J MicrobiolImmunol Infect 2010; 43:111-8.

20. Thwaites GE, Duc Bang N, Huy Dung N, ThiQuy H, ThiTuongOanh D, Thi Cam Thoa N, et al. The influence of HIV infection on clinical presentation, response to treatment, and outcome in adults with Tuberculosis meningitis. J Infect Dis.2005; 192:2134-41.

21. Ingole R, Garg RK, Malhotra HS, Jain A, Kumar N, Rizvi I, Garg R. Spectrum of central nervous system tuberculosis: An experience from a large tertiary care institution of India. Indian Journal of Tuberculosis. 2017 Jun 16.

22. Li, K., Tang, H., Yang, Y., Li, Q., Zhou, Y., Ren, M., Long, X., Shen, W., Hu, R., Wang, X. and Zeng, K. Clinical features, long-term clinical outcomes, and prognostic factors of tuberculous meningitis in West China: a multivariate analysis of 154 adults. 2017.
23. Christensen AS, Andersen AB, Thomsen VO, Andersen PH, Johansen IS Tuberculosis meningitis in Denmark: a review of 50 cases. BMC Infect Dis. 2011;11:47.

24. Gambhir IS, Mehta M, Singh DS, Khanna HD. Evaluation of CSFadenosine deaminase activity in tubercular meningitis. $\mathbf{J}$ Assoc Physicians India. 1999; 47:192-94.

25. Lee SW, Kang YA, Yoon YS, Um S, Lee SM, Yoo C, et al. The Prevalence and Evolution of Anemia Associated with Tuberculosis. J Korean Med Sci 2006; 21: 1028-32.

26. Cotton MF, Donald PR, Schoeman JF, Aalbers C, Van Zyl LE, Lombard C. Plasma arginine vasopressin and the syndrome of inappropriate antidiuretic hormone secretion in tuberculous meningitis, Pediatr. Infect. Dis. J. 1991;10:837-2.

27. Singh BS, Patwari AK, Deb M. Serum sodium and osmolal changes in tuberculous meningitis, Indian Pediatr. 1994; 31:1345-50.

28. Christopher R, Gourie-Devi M. The syndrome of inappropriate antidiuretic hormone secretion in tuberculous meningitis, J. Assoc. Physicians India.1997;45: 933-5.

29. Patwari AK, Singh BS, Manorama DE, Inappropriate secretion of antidiuretic hormone in acute bacterial meningitis, Ann. Trop. Paediatr. 1995;15: 179-183.

30. Kee CP, Periyasamy P, Law ZK, Ibrahim NM, Features and Prognostic Factors of Tuberculous Meningitis in a Tertiary Hospital in Malaysia $\mathbf{J}$ Infect Dis Epidemiol 2017, 3:028.

31. Davis LE, Rastogi KR, Lambert LC, Skipper BJ. Tuberculous meningitis in the southwest United States: a community based study. Neurology 1993;43:1775-8.

32. Berger JR. Tuberculous meningitis. CurrOpinNeurol 1994;7:191-200.

Copyright: (C) the author(s), 2019. It is an open-access article distributed under the terms of the Creative Commons Attribution License (CC BY 4.0), which permits authors to retain ownership of the copyright for their content, and allow anyone to download, reuse, reprint, modify, distribute and/or copy the content as long as the original authors and source are cited.

How to cite this article: Malik VS, Singh VK. Study of Clinical Correlates of Tubercular Meningitis in a Tertiary Care Centre in Moradabad.Acad. J Med. 2019;2(2):200-06.

DOI: dx.doi.org/10.21276/ajm.2019.2.2.51

Source of Support: Nil, Conflict of Interest: None declared. 